\title{
Spatial variation in the reproductive biology of Paralvinella palmiformis (Polychaeta: Alvinellidae) from a vent field on the Juan de Fuca Ridge
}

\author{
Jonathan T. P. Copley ${ }^{1, *}$, Paul A. Tyler ${ }^{1}$, Cindy L. Van Dover ${ }^{2}$, Steven J. Philp ${ }^{1}$ \\ ${ }^{1}$ School of Ocean and Earth Science, Southampton Oceanography Centre, University of Southampton, European Way, \\ Southampton SO14 3ZH, United Kingdom \\ ${ }^{2}$ Biology Department, College of William \& Mary, Williamsburg, Virginia 23187, USA
}

\begin{abstract}
The microdistribution and dynamics of deep-sea hydrothermal vent communities often reflect the extreme heterogeneity of their environment. Here we present an assessment of spatial variation in the reproductive development of the alvinellid polychaete Paralvinella palmiformis at the High Rise vent field (Endeavour Segment, Juan de Fuca Ridge, NE Pacific). Samples collected from different locations across the vent field suggest patchy reproductive development for this species. Males and females from several locations contained few or no developing gametes, while gametes were abundant in samples collected at the same time from other locations. Samples lacking gametes were distinguished by body size-frequency distributions with peaks at smaller sizes and the presence or absence of other fauna consistent with early stage assemblages in a successional mosaic model previously proposed for Endeavour Segment communities. Where gametes were present, synchrony of reproductive development between females within samples and between samples was evident. Reproductive synchrony between pairs of samples initially declined over a $7 \mathrm{~d}$ interval between samples, suggesting a rapid rate of reproductive development for $P$. palmiformis. Samples collected 1 mo apart, however, displayed similar frequency distributions of developing gametes. A peak of mature male and female gametes appeared to develop and disappear within the limited temporal resolution of the samples, consistent with possible simultaneous maturation of gametes despite pseudocopulation and sperm storage in this species.
\end{abstract}

KEY WORDS: Hydrothermal vents - Reproductive development - Spatio-temporal variation . Successional model

- Resale or republication not permitted without written consent of the publisher

\section{INTRODUCTION}

Deep-sea hydrothermal vent communities are remarkable for their use of geothermal energy in the fixation of inorganic carbon and the often specialised physiology, biochemistry and bacterial symbioses exhibited by their member species (reviewed by Childress \& Fisher 1992). But while these features have been the subjects of intense investigation, our knowledge of the reproductive biology of vent organisms remains fragmentary. Until recently, less than 10 species were involved in studies primarily addressing reproductive questions (Tyler \& Young 1999), although this number is growing (Jollivet et al. 2000, Ramirez Llodra et al. 2000, Marsh et al. 2001).

Hydrothermal vents are also remarkable for spatial variation in the microdistribution of fauna around them (e.g. Fustec et al. 1987, Segonzac 1992, Chevaldonné \& Jollivet 1993, Van Dover et al. 1996, Copley et al. 1997, Sarrazin et al. 1997, Gebruk et al. 2000), which may reflect heterogeneity in physico-chemical conditions and biological interaction (Hessler \& Smithey 1983, Hessler et al. 1985, Grassle 1986, Sarrazin \& Juniper 1999, Sarrazin et al. 1999). Studies of the reproductive development of vent organisms, however, have been almost exclusively based on single or pooled samples 
of a particular species (e.g. McHugh 1989, McHugh \& Tunnicliffe 1994), revealing little about the spatial variability of reproductive development in the heterogeneous vent environment.

The aim of this study is to examine spatial variability in the reproductive development of the alvinellid polychaete Paralvinella palmiformis from the High Rise vent field on the Endeavour Segment of the Juan de Fuca Ridge, NE Pacific (Fig. 1). Vent communities on the Endeavour Segment are believed to comprise a mosaic of decimetre- to metre-scale patches, each undergoing successional changes on a subannual timescale (Sarrazin et al. 1997, 1999, Sarrazin \& Juniper 1999). P. palmiformis makes a substantial contribution to the faunal assemblages involved in this successional model.

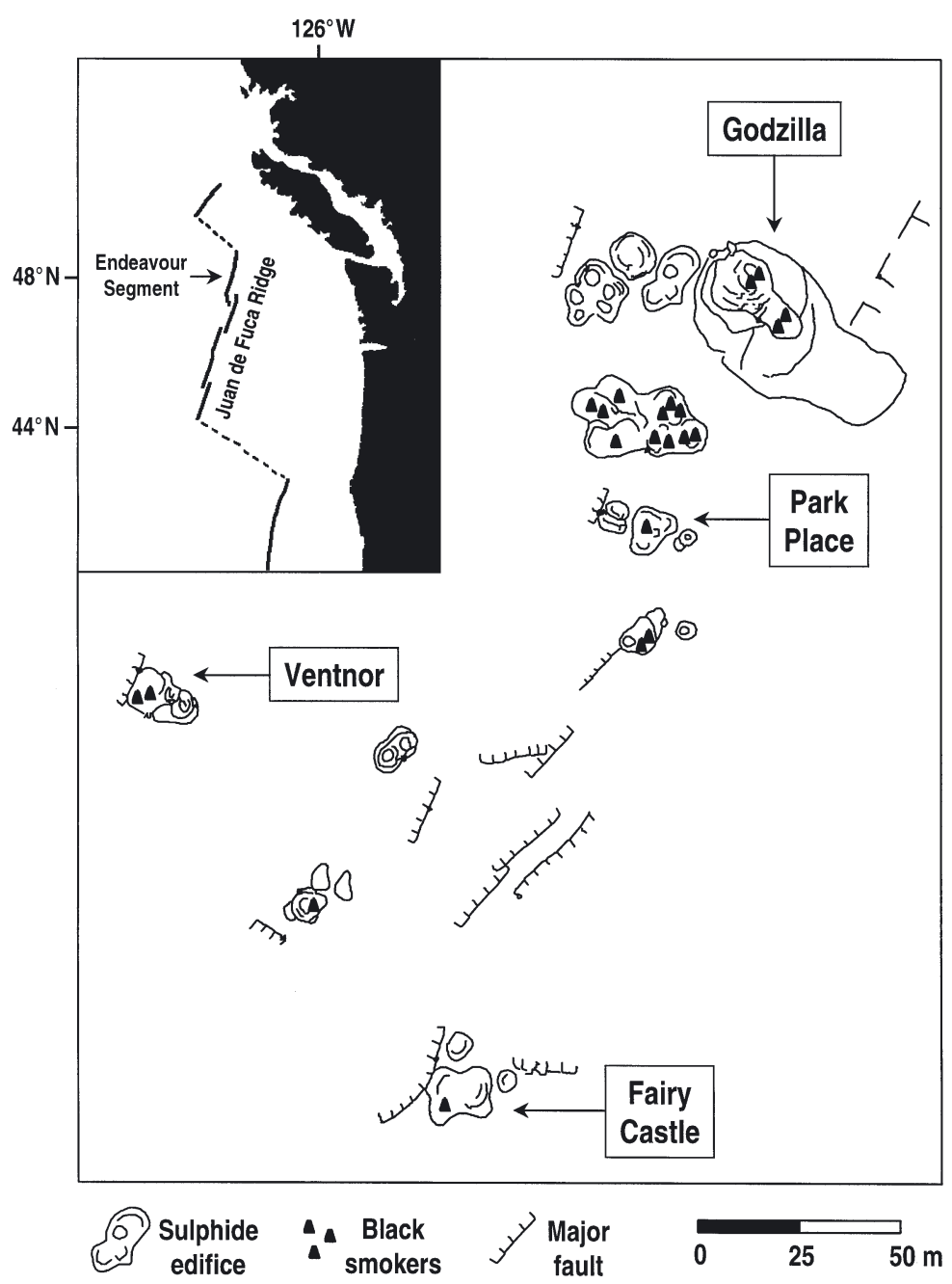

Fig. 1. Location map of Endeavour Segment, Juan de Fuca Ridge (inset) and distribution of the named sulphide structures of the High Rise vent field where samples were collected (after Robigou et al. 1993)
Recently formed or denuded mineral surfaces in the vent field are colonised by the motile pioneer species Paralvinella sulfincola (Juniper et al. 1992, Tunnicliffe et al. 1993), which forms the biomass dominant in the earliest assemblage (Sarrazin \& Juniper 1999). Mucus secretion by $P$. sulfincola promotes the formation of a marcasite crust on vent chimneys that may facilitate subsequent colonisation by $P$. palmiformis (Juniper et al. 1992, Tunnicliffe et al. 1993).

Paralvinella palmiformis displays slightly lower tissue-level sulphide detoxification rates than $P$. sulfincola (Martineu et al. 1997), suggesting that it may be adapted to less severe hydrothermal conditions (Sarrazin \& Juniper 1999). It has been proposed that $P$. palmiformis deposes $P$. sulfincola as the biomass dominant as succession progresses. The gastropods Lepetodrilus fucensis and Depressigyra globulus also make progressively greater proportional contributions to biomass at later successional stages. Interspecific competition with these deposit feeders has been hypothesised to restrict $P$. sulfincola to more extreme habitat conditions, whilst having less impact on suspensionfeeding $P$. palmiformis (Sarrazin \& Juniper 1999).

Eventually assemblage biomass is dominated by the vestimentiferan tubeworm Ridgeia piscesae, which grows up through the background of gastropods and Paralvinella palmiformis. Vestimentiferan tubes may provide a substratum for a wider range of species in this assemblage. Some species may be excluded in conditions of high hydrothermal flow, however, and $P$. palmiformis and $P$. sulfincola may flourish again among the vestimentiferans in such areas (Sarrazin \& Juniper 1999). R. piscesae from such high-flow regimes are morphologically distinct to specimens from the low-flow assemblage, with wide white tubes and prominent branchial plumes (Southward et al. 1995).

Alteration of local hydrothermal flow can reset the succession; therefore the vent community is envisioned to comprise a mosaic of patches, each possibly at a different successional stage to its neighbours and cycling independently in response to local environmental fluctuations. Videoscopic observations of a sulphide edifice on the Endeavour Segment over $4 \mathrm{yr}$ indicate that the progression from an assemblage dominated by Paralvinella sulfincola to one dominated by vestimentiferans can occur on a subannual timescale (Sarrazin et al. 1997). Sarrazin \& Juniper (1999) recognise several distinct assemblages involved in this successional sequence (Fig. 2). 
Fig. 2. Dynamic successional model of Sarrazin \& Juniper (1999) for Endeavour Segment hydrothermal vent communities. Most abundant species (ind. $\mathrm{m}^{-2}$ ) of each assemblage are presented following data of Sarrazin \& Juniper (1999). Main agents of successional change are flow modifications and biological processes such as growth and habitat alteration through biomineralisation. Perturbations that do not alter flow regimes may permit progressive recolonisation by the original assemblage
New high-temperature surface

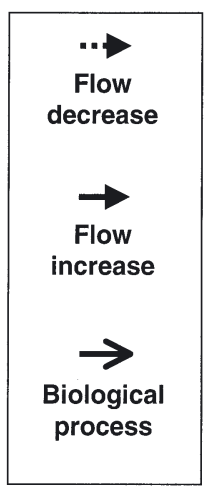

McHugh (1989) examined the reproductive development of Paralvinella palmiformis in 3 samples collected from the Endeavour segment in July, August and September 1984. Very few or no oocytes were found in females from the samples collected in August and September, but oocytes were present in females from the July sample. Samples without oocytes were interpreted as having just spawned, suggesting discontinuous reproduction with a possibly discrete breeding period for this species. However, as each sample was collected from a different location within the vent on each occasion, spatial variation in reproductive development was not addressed.

McHugh (1989) also suggested some synchronisation of reproductive development may occur between female Paralvinella palmiformis, as mean oocyte size did not differ significantly among more than half the individuals in the sample containing oocytes. Similar evidence for synchrony of reproductive development is known in $P$. grasslei on the East Pacific Rise, which shares many ecological similarities with $P$. palmiformis (Desbruyères \& Laubier 1986). Zal et al. (1995) found no significant differences between the oocyte sizefrequency distributions of female $P$. grasslei within a single sample, suggesting synchrony of reproductive development, but providing no indication of the spatial scale over which such synchrony might extend.

The present study addresses the following questions: (1) Is there spatial variation in the reproductive development of Paralvinella palmiformis across the vent field? (2) Does any spatial variation in reproductive development reflect the successional mosaic of the vent community? (3) Is there evidence of synchrony of

Inactive surface extend?
Most abundant species (individuals $\mathrm{m}^{-2}$ )

Paralvinella sulfincola

P. sulfincola \&

P. palmiformis

Lepetodrilus fucensis \& Depressigyra globulus

Ridegia piscesae \& L. fucensis

R. piscesae ("skinny" / "fat")

Senescent assemblage

reproductive development between individuals, and if so, over what spatial and temporal scales does it

A simple null hypothesis would be that reproductive development is uniform and synchronous across the vent field, with all the mature females exhibiting the same stage of reproductive development at any one time. Given the heterogeneity of the vent environment, such a null hypothesis seems likely to be rejected, though this is the first study to address this question. However, this null hypothesis is an implicit assumption in previous studies that have used single samples from different locations at different times to make inferences about temporal patterns of reproductive development at vents (e.g. McHugh 1989). Understanding spatial variation would seem to be an important prerequisite for future sampling programmes seeking to determine temporal variation in reproductive development at vents.

\section{MATERIALS AND METHODS}

The High Rise vent field $\left(47^{\circ} 58.00^{\prime} \mathrm{N}, 129^{\circ} 05.50^{\prime} \mathrm{W}\right)$ was discovered during reconnaissance dives to the north of the Main Endeavour field in 1988 and mapped in 1991 (Robigou et al. 1993). The vent field is situated on a central horst within the narrow axial valley of the Endeavour Segment. It comprises of a core of large, actively venting structures with additional smaller, less active and dead spires within an area $350 \mathrm{~m}$ along the valley by $150 \mathrm{~m}$ across it (Fig. 1). At one point, the vent field contained the tallest single hydrothermal edifice 
reported in the Pacific Ocean ('Godzilla', $45 \mathrm{~m}$ tall); however, this structure collapsed between 1995 and 1996 (Juniper et al. 1996). All the large sulphide structures in the vent field support flanges extending horizontally from their sides. Basal cavities under these flanges can trap pools of hydrothermal effluent with similar composition and temperature to black smoker fluid (Delaney et al. 1992).

Samples of invertebrates were collected from different locations across the vent field in September and October 1995, using the mechanical grabs of DSV 'Sea Cliff' and the US Navy's Advanced Tethered Vehicle (ATV), a ROV system. Each sample was taken from an area $<1 \mathrm{~m}^{2}$ and stored in a separate box in the submersible basket. Fauna were sorted to major taxa on board, fixed in $10 \%$ buffered seawater formalin and preserved in $70 \%$ isopropanol, used in place of ethanol for ease of transporting samples through customs. Nine samples of Paralvinella palmiformis were isolated for reproductive studies (Table 1). Details of the other fauna in the samples were noted to provide information about the type of assemblage from which they came.

The dorsal width of the seventh setiger (S7) of 300 worms was also measured in each sample, as this provides an index of body size for terebellomorph polychaetes (Olive \& Clark 1978, Guillou \& Hily 1983, McHugh 1989, Zal et al. 1995). The segment is rigid and easily recognisable as it carries large modified hooks (Desbruyères \& Laubier 1986). Measurements of segment width were made under a Leica MZ8 stereomicroscope with a camera lucida and digitising tablet as before.

Female worms were distinguished by the absence of lateral cavities on the peristomium and the lack of trilobate tentacles, as in Paralvinella grasslei (Zal et al. 1994). Oocytes develop freely in the coelom of terebellomorph polychates, and coelomic fluid from 15 females drawn at random from each sample was extracted by pipette after cutting through the body wall of the trunk (Olive 1970). This extract was placed on a Weber Scientific haemocytometer and examined at $400 \times$ magnification under an Olympus $\mathrm{BH}-2$ compound microscope. Where present, the maximum elliptical diameters of 70 oocytes per female were measured under the microscope, using a camera lucida to simultaneously view a Summagraphics MM1812 Bitpad digitising tablet interfaced to a PC running Jandel Scientific SigmaScan software (Version 3.92). Oocyte shrinkage is known to occur during fixation, but is assumed to affect all oocytes, thereby preserving relative patterns.

Intrasample synchrony of female reproductive development was determined using a Kruskal-Wallis multi-sample test to compare the oocyte size-frequency distributions of individuals within each sample (Zal et al. 1995). Where there were significant differences between the oocyte size-frequency distributions, a multiple range test using the Student-Newman-Keuls (SNK) procedure was employed to identify which females contributed to this result. The remaining females showed no significant differences in oocyte size-frequency distributions and may therefore be considered to exhibit synchrony of reproductive development (McHugh 1989, Zal et al. 1995).

Intersample female reproductive synchrony was determined by comparing the oocyte size-frequency distributions of females displaying synchrony in 1 sample with those females displaying synchrony in another. Kruskal-Wallis multi-sample tests were again used to compare the oocyte size-frequency distributions of females in these pairs of synchronous groups. Where there were significant differences, a multiple range test by the SNK method was used again to compare the oocyte-size frequency distribution of each female with that of every other female in the 2 groups, thereby determining the proportion of females in the 2

Table 1. Summary of sample collection details, presence/absence of developing gametes and putative assemblage type represented by each sample on the basis of other fauna (see text for details). Numbers associated with some sample names relate to markers deployed during collection

\begin{tabular}{|lccccc|}
\hline Sample & Dive & $\begin{array}{c}\text { Date } \\
(1995)\end{array}$ & $\begin{array}{c}\text { Developing } \\
\text { oocytes }\end{array}$ & $\begin{array}{c}\text { Developing } \\
\text { sperm }\end{array}$ & $\begin{array}{c}\text { Assemblage based } \\
\text { on other fauna }\end{array}$ \\
\hline Park Place \#64 & DSV 'Sea Cliff' \#996 & 02 Sep & None/few, small & None/few & II \\
Ventnor \#71 & DSV 'Sea Cliff' \#996 & 02 Sep & None/few, small & None/few & II/III \\
Fairy Castle \#68 & DSV 'Sea Cliff' \#997 & 04 Sep & None/few, small & - & I/II \\
Ventnor \#63 & DSV 'Sea Cliff' \#998 & 05 Sep & None/few, small & None/few & II/III I \\
Park Place \#67 & DSV 'Sea Cliff' \#998 & 05 Sep & Present & Present & IV/V-LF \\
Park Place 'no marker' & DSV 'Sea Cliff' \#999 & 10 Sep & Present & Present & IV/V-LF \\
Godzilla & ATV \#95-51-152 & 12 Sep & Present & Present & V-HF \\
Park Place 'near top' & DSV 'Sea Cliff' \#1004 & 05 Oct & Present & Present & IV \\
Park Place 'left of \#67' & DSV 'Sea Cliff' \#1004 & 05 Oct & Present & IV & \\
\hline
\end{tabular}


samples that showed no significant differences in oocyte size-frequency distributions.

Male reproductive development was assessed in 7 of the 9 samples, as 2 samples (Fairy Castle \#68 and Park Place 'near top') perished after the examination of female reproductive development. Twenty male worms from each sample were dehydrated in graded alcohols, cleared in histoclear and embedded in paraffin wax. Sections were cut at $7 \mu \mathrm{m}$ and stained with Mayer's haemalum and eosin. The frequency of 3 stages of sperm development was noted, following the scheme described by Hutchings (1973) and Guillou \& Hily (1983) for other terebellomorphs, also used by McHugh (1989): (1) single spermatogonia or spheres of 2 to 8 cells formed by the division of spermatogonia; (2) rosettes of spermatocytes and larger rosettes of early spermatids; (3) morulae composed of spermatids. Sections were examined at random using an Olympus BH-2 compound microscope at $400 \times$ magnification until a count of 80 spermatogenic stages was reached.

\section{RESULTS}

\section{Reproductive development}

Four of the subsamples of female Paralvinella palmiformis contained no or very few small oocytes (Table 1), even when over 30 individuals were examined, including deliberately selected larger specimens. All the females examined in the other 5 samples contained oocytes. Very few or no developing sperm were found in males examined from 3 samples: Ventnor \#71, Ventor \#63 and Park Place \#64 (Table 1); these were samples where oocytes were also absent in females.

In the samples with oocytes, the oocyte sizefrequency distributions of individual females were significantly different from normal (Kolmogorov-Smirnov tests of normality; all failed, $\mathrm{p}<0.0001$ ). There were

Table 2. Paralvinella palmiformis. Intrasample synchrony of female reproductive development from the High Rise vent field

\begin{tabular}{|lllc|}
\hline Sample & $\begin{array}{c}\text { Kruskal-Wallis multi- } \\
\text { sample test (14 df) }\end{array}$ & $\begin{array}{c}\text { SNK multiple } \\
\text { range test }\end{array}$ & $\begin{array}{c}\text { Intrasample } \\
\text { synchrony (\%) }\end{array}$ \\
\hline Park Place \#67 & $\mathrm{H}^{*}=96.8, \mathrm{p}<0.0001$ & 5 different & 67 \\
Park Place 'no marker' & $\mathrm{H}^{*}=35.3, \mathrm{p}=0.0013$ & 3 different & 80 \\
Godzilla & $\mathrm{H}^{*}=25.3, \mathrm{p}=0.0319$ & 1 different & 93 \\
Park Place 'near top' & $\mathrm{H}^{*}=105,8, \mathrm{p}<0.0001$ & 7 different & 53 \\
Park Place 'left of \#67' & $\mathrm{H}^{*}=75.7, \mathrm{p}<0.0001$ & 6 different & 60 \\
\hline
\end{tabular}

significant differences between the oocyte sizefrequency distributions of the females within each sample (Fig. 3; Table 2). However, multiple range tests of females within each sample by the SNK procedure showed that only a minority of females contributed to this result in most cases. The proportion of females that showed no significant difference in oocyte sizefrequency distributions ranged from 53 to $93 \%$ of the females examined in each sample (Table 2). Females from Godzilla showed the highest level of such intrasample synchrony, with only 1 female of those examined differing significantly from the others in oocyte sizefrequency distribution.

Comparing the oocyte size-frequency distributions of synchronous females in each sample with those of other samples, 5 out of 10 pairs of samples showed no significant differences 
Table 3. Paralvinella palmiformis. Intersample synchrony of female reproductive development from the High Rise vent field

\begin{tabular}{|c|c|c|c|c|}
\hline & $\begin{array}{l}\text { Park Place 'no marker' } \\
\text { (IV/V-LF) }\end{array}$ & $\begin{array}{l}\text { Godzilla } \\
\text { (V-HF) }\end{array}$ & $\begin{array}{l}\text { Park Place 'near top' } \\
\text { (IV) }\end{array}$ & $\begin{array}{c}\text { Park Place 'left of \#67' } \\
\text { (IV) }\end{array}$ \\
\hline $\begin{array}{l}\text { Park Place \#67 } \\
\text { (IV/V-LF) }\end{array}$ & $\begin{array}{c}\mathrm{H}^{*}=61.2, \mathrm{p}<0.0001,21 \mathrm{df} \\
\text { SNK: } 5 \text { different }(71 \%)\end{array}$ & $\begin{array}{c}\mathrm{H}^{*}=90.3, \mathrm{p}<0.0001,23 \mathrm{df} \\
\text { SNK: } 9 \text { different }(63 \%)\end{array}$ & $\begin{array}{c}\mathrm{H}^{*}=24.5, \mathrm{p}>0.05,16 \mathrm{df} \\
(100 \%)\end{array}$ & $\begin{array}{c}\mathrm{H}^{*}=28.1, \mathrm{p}>0.05,18 \mathrm{df} \\
(100 \%)\end{array}$ \\
\hline $\begin{array}{l}\text { Park Place 'no } \\
\text { marker' (IV/V-LF) }\end{array}$ & - & $\begin{array}{c}\mathrm{H}^{*}=41.3, \mathrm{p}=0.0212,25 \mathrm{df} \\
\text { SNK: } 1 \text { different }(96 \%)\end{array}$ & $\begin{array}{c}\mathrm{H}^{*}=26.5, \mathrm{p}>0.05,18 \mathrm{df} \\
(100 \%)\end{array}$ & $\begin{array}{c}\mathrm{H}^{*}=31.1, \mathrm{p}>0.05,20 \mathrm{df} \\
(100 \%)\end{array}$ \\
\hline $\begin{array}{l}\text { Godzilla } \\
\text { (V-HF) }\end{array}$ & - & - & $\begin{array}{c}\mathrm{H}^{*}=35.5, p=0.0176,20 \mathrm{df} \\
\text { SNK: } 2 \text { different }(90 \%)\end{array}$ & $\begin{array}{c}\mathrm{H}^{*}=37.3, \mathrm{p}=0.0217,22 \mathrm{df} \\
\text { SNK: } 1 \text { different }(96 \%)\end{array}$ \\
\hline $\begin{array}{l}\text { Park Place 'near } \\
\text { top' (IV) }\end{array}$ & - & - & - & $\begin{array}{c}\mathrm{H}^{*}=15.0, \mathrm{p}>0.05,15 \mathrm{df} \\
(100 \%)\end{array}$ \\
\hline
\end{tabular}

(Table 3). For the 5 sample pairs where significant differences were present, all-pairwise multiple comparison by the SNK method indicated that these differences could be attributed to just a few worms in each case. The degree of intersample synchrony of reproductive development therefore ranged from 63 to $100 \%$ among females displaying intrasample synchrony (Table 3).

\section{S7 size-frequency distributions}

The size-frequency distributions of the S7 widths measured in each sample differed significantly from normal (Fig. 4; KolmogorovSmirnov tests of normality, all failed, $\mathrm{p}<0.05$ ). A Kruskal-Wallis multi-sample test revealed significant differences between the distributions $\left(\mathrm{H}^{*}=1710, \mathrm{p}<0.0001,8 \mathrm{df}\right)$, but a multiple range test identified 2 groups of samples that had no significant differences between them.

One of these groups consisted of samples collected from Ventor \#63, Ventnor \#71, Park Place \#64 and Fairy Castle \#68. The S7 size-frequency distributions of these samples showed peak frequencies at smaller S7 widths than the other samples and a smaller maximum worm sizes (Fig. 4). These samples were also those where developing gametes were not present.

There were no significant differences between the S7 size-frequency distributions of worms from Park Place 'no marker', Park Place 'near top', Park Place \#67 and Park Place 'left of 67'. The S7 size-frequency distribution of worms from Godzilla, however, was significantly different from all other samples, as this sample generally contained much larger specimens (Fig. 4).
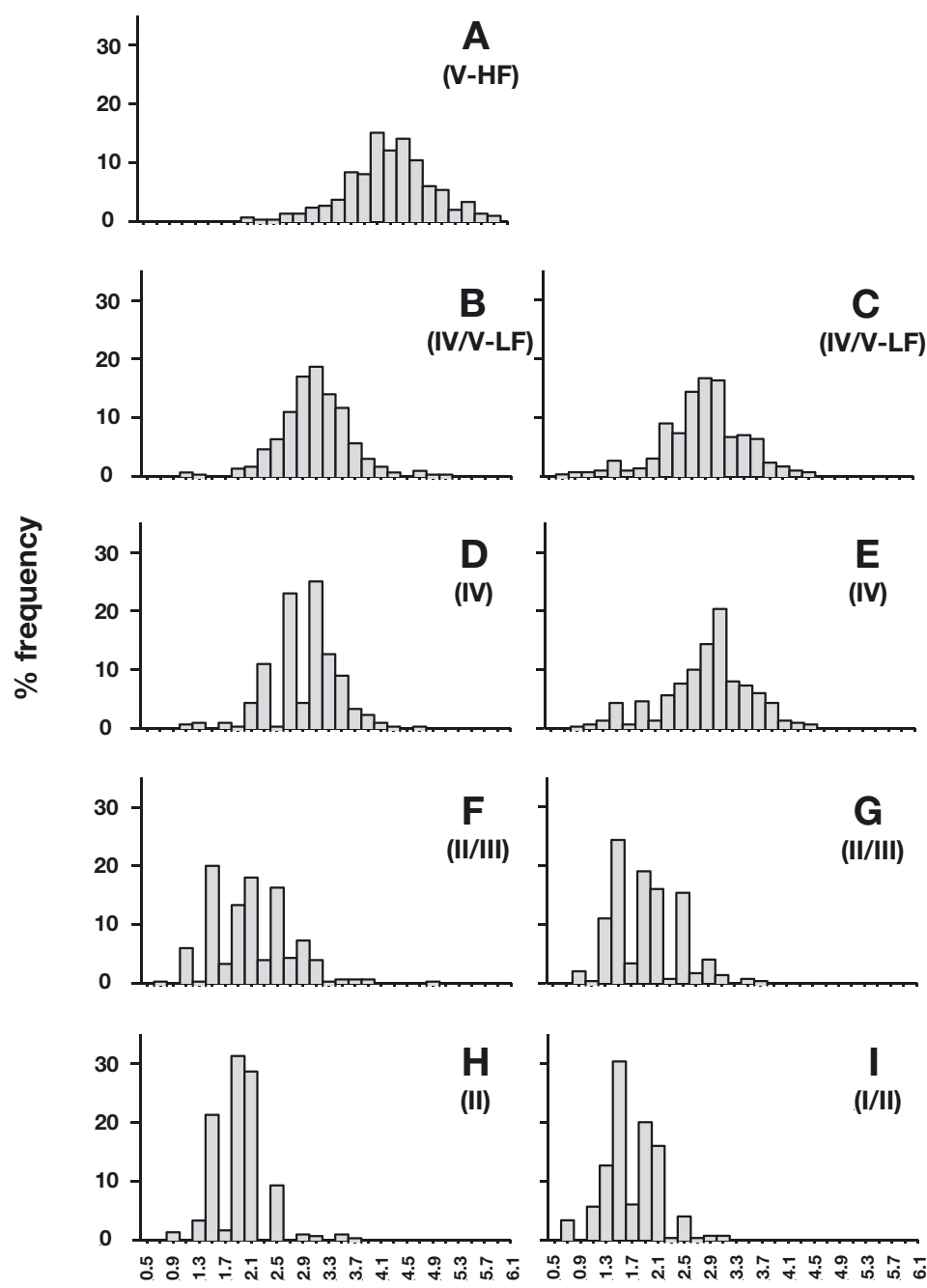

\section{S7 width (mm)}

Fig. 4. Paralvinella palmiformis. Size-frequency distributions of dorsal seventh setiger (S7) widths from the High Rise vent field. A: Godzilla, B: Park Place 'no marker', C: Park Place \#67, D: Park Place 'near top', E: Park Place 'left of \#67', F: Ventnor \#63, G: Ventnor \#71, H: Park Place \#64, I: Fairy Castle \#68. Putative assemblage types are denoted in brackets; $\mathrm{n}=300$ worms measured in each sample 


\section{Other fauna}

Although sampling by the submersible arm was not quantitative, Paralvinella sulfincola were most common in 3 out of the 4 samples where $P$. palmiformis lacked gametes (Park Place \#64, Fairy Castle \#68 and Ventnor \#71). This pioneer species dominates the earliest stage assemblage of the successional mosaic model proposed by Sarrazin et al. (1997) and refined by Sarrazin \& Juniper (1999).

All the samples of Paralvinella palmiformis lacking gametes also contained few Depressigyra globulus, Lepetodrilus fucensis and Ridegia piscesae compared to the other samples. The polychaete Amphisamytha galapagensis and aplacophoran Helicoradomenia juani were common in the sample from Fairy Castle \#68, also consistent with an area occupied by the earliest stage assemblages (Sarrazin \& Juniper 1999).

Depressigyra globulus and Lepetodrilus fucensis were more abundant in the 4 samples where Paralvinella palmiformis contained gametes and had similar and larger S7 size-frequency distributions (Park Place \#67, Park Place 'no marker', Park Place 'near top' and Park Place 'left of 67'). Ridegia piscesae were also more abundant and larger in these samples than those where $P$. palmiformis lacked gametes, though all $R$. piscesae specimens exhibited 'skinny' morphology with thin tubes and poorly developed branchial filaments (Southward et al. 1995). P. sulfincola were rare or absent in these samples.

Nicomache venticola were present in the sample from Park Place 'no marker'; this capitellid polychaete is only reported from Assemblage IV (Sarrazin \& Juniper 1999). Helicoradomenia juani were common in the sample from Park Place \#67 and this species is known to dominate the small fauna in Assemblage V-LF.

Ridegia piscesae in the sample collected from Godzilla had wide, white tubes and prominent, feathery branchial plumes indicative of Assemblage V-HF (Sarrazin et al. 1997). There were no Depressigyra globulus in this sample and only a few Lepetodrilus fucensis, which were larger than in the other samples. $P$. sulfincola were more common in the sample from Godzilla than the other samples, where Paralvinella palmiformis exhibited developing gametes, again consistent with an area containing Assemblage V-HF.

On the basis of the presence or absence of these other fauna, assemblages putatively assigned to samples are presented in Table 1. While a posteriori inference of assemblages must be made with caution and some contamination from areas containing other assemblages is likely, the samples are broadly divided into 2 groups of early (I/II to II/III) and later (IV to V) assemblages.

\section{DISCUSSION}

\section{Reproductive development and the successional mosaic model}

Reproductive development of Paralvinella palmiformis does not appear to be uniform across the vent field, with few or no gametes present in 4 of the samples examined. This variation is clearly spatial and not temporal, as 1 sample with gametes (Park Place \#67) was collected within $4 \mathrm{~h}$ of a sample with few or no gametes (Ventnor \#71) during the same dive. The variation is also on a finer scale than that of an individual sulphide edifice, as samples with and without gametes were both collected from Park Place. One sample (Godzilla) was collected using a different sampling platform to the others, but using similar submersible manipulator technology and approach.

Two features distinguish the samples of Paralvinella palmiformis lacking gametes from those where gametes are present. The samples with few or no gametes have S7 size-frequency distributions with smaller maximum sizes (Fig. 4) and may have come from areas predominantly containing Assemblages I to III following the scheme of Sarrazin \& Juniper (1999), although samples were assigned to assemblages a posteriori as the successional mosaic model had not been proposed when the samples were collected. The samples containing abundant gametes appear to span Assemblages IV to V (Table 1), with the morphology of Ridegia piscesae in the sample collected from Godzilla clearly showing that this sample came from an area containing high-flow Assemblage V (V-HF).

Spatial variation in reproductive development of Paralvinella palmiformis may therefore reflect the successional mosaic of the vent community, with specimens from earlier successional stages being reproductively immature. Although physical and chemical parameters such as temperature or sulphide concentration were not measured in this study and would provide an environmental context for each sample, the different assemblages of the successional mosaic model are known to lie along a cline of habitat condition (Sarrazin et al. 1999). Assemblages I and II occupy the most 'severe' hydrothermal niche and Assemblages III to V occupy more clement habitats, though biological factors such as competition may also be important in influencing species distributions (Sarrazin et al. 1999).

While Paralvinella sulfincola can migrate rapidly to colonise new sulphide surfaces as a pioneer species (Tunnicliffe et al. 1993), the motility of $P$. palmiformis is less clear. $P$. palmiformis may be unable to migrate from Assemblages I and II to regions where conditions may be more conducive to reproductive development, 
as competition for space is considered to be an important factor in mature vent communities (Hessler et al. 1985) and is likely to be more apparent at later stages in the successional mosaic model. Habitats hosting later-stage assemblages are therefore likely to be already occupied. Habitat may only become available for colonisation where chimney growth creates new surfaces or disturbance clears an area, which resets succession where it involves the reactivation of fluid flow on cooling surfaces (Sarrazin et al. 1997).

\section{Spatial and temporal variation in reproductive development}

McHugh (1989) found no oocytes in single samples of Paralvinella palmiformis collected from different locations around Endeavour Segment vents in August and September 1984, but did find oocytes in a sample from July. The results of the present study suggest that this pattern could have been spatial, rather than temporal as originally interpreted.

McHugh (1989) considered 2 possible explanations for the lack of oocytes in some samples of Paralvinella palmiformis: either the worms were reproductively immature, or they had recently undergone complete spawning of their gametes. The former was discounted on the basis of developing gametes being present in worms of similar size from other samples. In the present study, however, it seems unlikely that the samples lacking gametes had just spawned. The degree of intersample synchrony in the reproductive development of samples containing oocytes would require at least 2 reproductive cycles with different phases to operate simultaneously in the vent field, with no clear segregation between edifices, for this interpretation to be valid.

The present study instead suggests that the samples lacking developing gametes are reproductively immature. If so, there may be some spatial variation in the size at which reproductive maturity occurs in Paralvinella palmiformis. Although there was some overlap in the S7 size-frequency distributions of worms with and without developing gametes, those without gametes exhibited peak frequencies at smaller sizes in this study and that of McHugh (1989). These populations could be younger, or growing more slowly if recruitment is synchronous across the vent field (McHugh 1989, Zal et al. 1995). Slow growth would be consistent with the animals occupying a more 'marginal' habitat, where maintenance costs are likely to be higher and less energy available for somatic growth and reproductive development.

Where gametes were present, there were indications of synchrony of female reproductive development

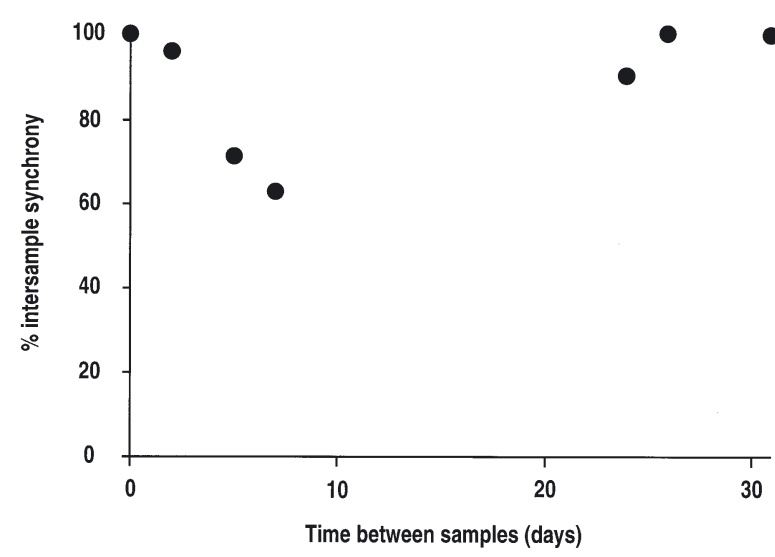

Fig. 5. Paralvinella palmiformis. Temporal variation in intersample synchrony of female reproductive development. Details of the determination of intersample synchrony are presented in Table 3

within samples, defined by a majority of females showing no significant differences in oocyte size-frequency distributions (McHugh 1989, Zal et al. 1995). With regard to the question of the scale over which such synchrony might extend, the proportion of such females showing no differences in oocyte sizefrequency distributions when pairs of samples were pooled and compared (intersample synchrony) ranged from 100 to $63 \%$ (Table 3). This variation does not appear to be related to differences in assemblage type, as samples from Godzilla (V-HF) and Park Place 'left of \#67' (IV) showed $96 \%$ synchrony, while Park Place \#67 and Park Place 'no marker' (both IV/V-LF) displayed synchrony of $71 \%$.

There is, however, 1 other variable expressed in the samples: time. The samples were collected over a period of $10 \mathrm{~d}$ during the first leg of the cruise and during the second leg 1 mo later. Intersample synchrony of female reproductive development initially decreases with time between pairs of samples (Fig. 5): samples collected on the same day show $100 \%$ intersample reproductive synchrony, falling to $63 \%$ between samples collected $7 \mathrm{~d}$ apart. However, samples collected approximately 1 mo apart show a greater proportion of intersample reproductive synchrony than samples collected $1 \mathrm{wk}$ apart-intersample synchrony rises to $>90 \%$ for samples collected $24 \mathrm{~d}$ apart ( 2 pairs) and returns to $100 \%$ for samples collected 26 and $31 \mathrm{~d}$ apart (Fig. 5).

The high level of synchrony of reproductive development between females collected from different locations on the same day suggests that there may be synchrony of female reproductive development across the vent field. If so, then the observation of an initial decline in reproductive synchrony with time between samples hints at a possible rapid rate of change in 
reproductive development for this species. Assuming that females were at the same state of reproductive development when the first sample of a pair was collected and fixed, any decline in intersample reproductive synchrony over time between samples could be attributed to changes in reproductive development during the period between samples.

The apparent return to high levels of reproductive synchrony among pairs of samples collected approximately 1 mo apart would be consistent with the pattern expected if females were following a monthly or fortnightly cycle of reproductive development. In such a cycle, oocyte growth or spawning would lead to a reduction in synchrony between samples collected 1 wk apart, but samples collected 1 mo apart would be at roughly the same stage of development. Reproductive cycles are typically annual for many polychaetes, but lunar or semi-lunar cycles have been reported for other terebellomorphs living in shallow water (Olive 1984). Zal et al. (1995) suggested that Paralvinella grasslei, which occupies a very similar habitat to $P$. palmiformis at East Pacific Rise vents (Desbruyères \& Laubier 1986), probably reproduces several times per year with an apparent periodicity.

Variability in the food supply from surface waters often drives reproductive periodicity in non-vent regions of the deep-sea at temperate latitudes (Tyler 1988). At vents, however, any seasonal input of organic matter from surface waters may be masked by the high level of autochthonous primary production. Growth rates at hydrothermal vents are an order of magnitude greater than elsewhere in the deep sea (Lutz \& Kennish 1993, Lutz et al. 1994); it would perhaps not be surprising, therefore, to encounter rapid rates of reproductive development at vents.

Among the male Paralvinella palmiformis, there are indications of an initial increase in the proportion of morulae and spermatids in the samples with time, but with the samples collected 1 mo apart showing similar proportions of developing sperm stages (Fig. 6). The peak frequency of morulae also coincides with a peak in the frequency of large oocytes in the samples
A

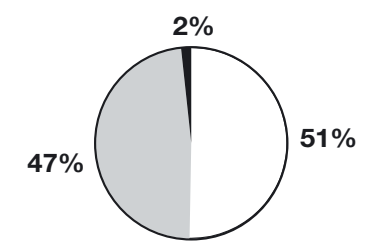

B

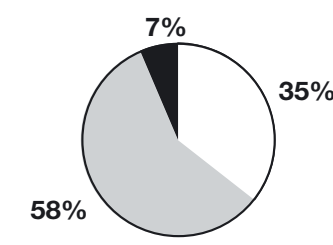

C

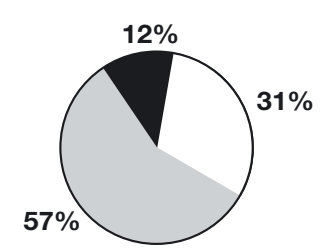

D

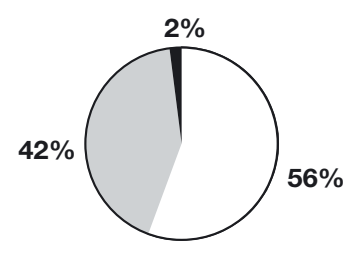

5 Sept

10 Sept

12 Sept

5 Oct

spermatogonia

spermatids

morulae
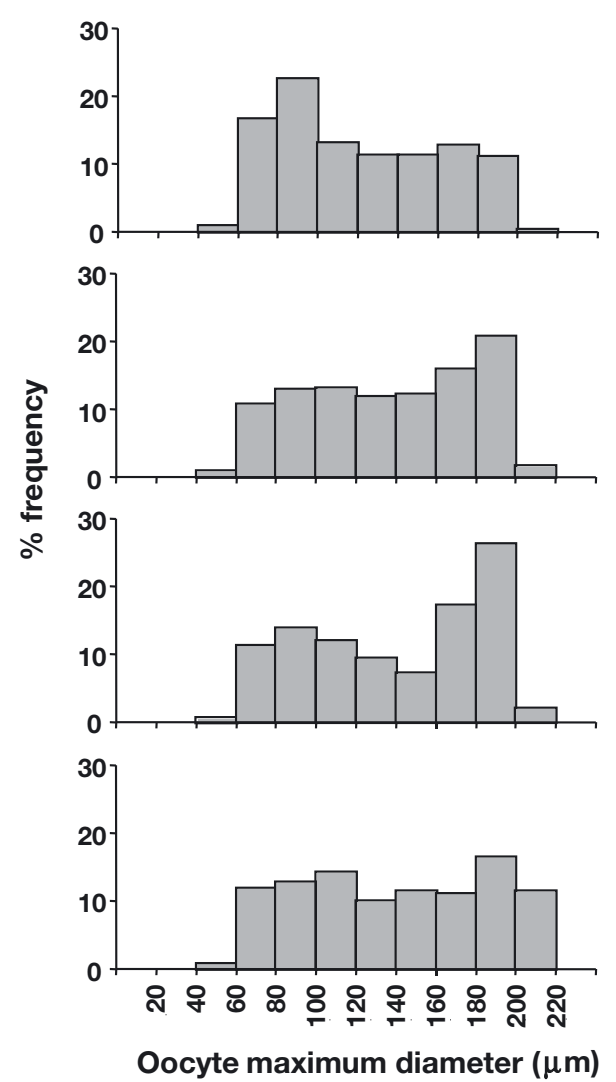

Fig. 6. Paralvinella palmiformis. Sperm development stages and pooled oocyte size-frequency distributions sampled from the High Rise vent field. Oocyte maximum diameter represents the major axis length of an elliptical oocyte. A: distribution for worms from Park Place \#67 ( $\mathrm{n}=1238$ sperm, 1050 oocytes); B: worms from Park Place 'no marker' ( $\mathrm{n}=1533$ sperm, 1050 oocytes); C: distribution for worms from Godzilla ( $\mathrm{n}=1577$ sperm, 1050 oocytes); D: distribution for males from Park Place 'left of \#67' (n = 1360 sperm) and females from Park Place \#67 and Park Place 'near top' combined ( $\mathrm{n}=2100$ oocytes). Collection dates are shown for each sample 
(Fig. 6). Such possible synchronisation of reproductive development between males and females is perhaps curious in a species where females practice sperm storage (Zal et al. 1994). The prevalence and duration of sperm storage is not yet characterised for P. palmiformis, however, and it is possible that fertilisation success and victory in any sperm competition could depend on pseudocopulation as close to female maturity as possible.

Zal et al. (1995) proposed that tides might provide an environmental cue by which Paralvinella grasslei could synchronise their reproductive development on the East Pacific Rise. Semi-diurnal and diurnal periodicities have also been observed in the retractionextension behaviour of vestimentiferans at Axial Seamount (Tunnicliffe \& Juniper 1990), while temporal variation in the microdistribution of shrimp on a midAtlantic vent chimney may reflect tidal variation in effluent dispersal (Copley et al. 1999). Tidal variations in parameters such as temperature have been recorded in diverse hydrothermal settings (e.g. Chevaldonné et al. 1991, Schultz \& Elderfield 1997), including signals with lunar and semi-lunar frequencies.

A tidal cue could provide a spatially uniform signal for synchronising reproductive development over a wide area, as suggested by the samples examined in this study. If such a process is operating, however, then it takes place on top of the spatial variation in reproductive development resulting from the successional mosaic of the vent community. Testing the hypothesis that Paralvinella palmiformis may exhibit a short cycle of reproductive development, possibly synchronised by a low-frequency tidal cue, would require more intensive and extensive time-series sampling.

\section{CONCLUSION}

This study finds spatial variation in the reproductive development of Paralvinella palmiformis across the High Rise vent field. This variation may reflect the mosaic of the vent community, with no gametes present in samples from assemblages at early stages of the successional model previously proposed for Endeavour Segment communities. Where gametes are present, there is some evidence of synchrony of reproductive development between individuals in samples collected from different locations across the vent field. This pattern may be confounded, however, by apparent temporal variation in reproductive development during the month-long period of sampling.

These results highlight the importance of considering spatial variation and ecological context in future attempts to address temporal patterns of reproductive development in vent species. Hydrothermal vents are known to exhibit extreme heterogeneity in physical and chemical conditions and the microdistribution of fauna around them; this study shows that heterogeneity can also extend to biological processes such as reproduction.

Acknowledgements. The authors would like to thank the personnel of the US Navy Deep Submergence Unit and the crew of the DSV 'Laney Chouest' for their exceptional support and assistance during the collection of the samples. Fieldwork was supported through a NOAA National Undersea Research Program grant to CLVD. The helpful comments of 2 anonymous reviewers are gratefully acknowledged.

\section{LITERATURE CITED}

Chevaldonné P, Jollivet D (1993) Videoscopic study of deepsea hydrothermal vent alvinellid polychaete populations: biomass estimation and behaviour. Mar Ecol Prog Ser 95: 251-262

Chevaldonné $P$, Desbruyères $D$, Le Haître M (1991) Time series of temperature from three hydrothermal vent sites. Deep-Sea Res 38:1417-1430

Childress JJ, Fisher CR (1992) The biology of hydrothermal vent animals: physiology, biochemistry and autotrophic symbioses. Oceanogr Mar Biol Annu Rev 30:337-441

Copley JTP, Tyler PA, Murton BJ, Van Dover CL (1997) Spatial and interannual variation in the faunal distribution at Broken Spur vent field (29 N, Mid-Atlantic Ridge). Mar Biol 129:723-733

Copley JTP, Tyler PA, Van Dover CL, Schultz A, Dickson P, Singh S, Sulanowska M (1999) Subannual temporal variation in faunal distributions at the TAG hydrothermal mound $\left(26^{\circ} \mathrm{N}\right.$, Mid-Atlantic Ridge). PSZN: Mar Ecol 20: 291-306

Delaney JR, Robigou V, McDuff RE, Tivey MK (1992) Geology of a vigorous hydrothermal system on Endeavour Segment, Juan de Fuca Ridge. J Geophys Res 97:19663-19682

Desbruyères D, Laubier L (1986) Les Alvinellidae, une famille nouvelle d'annélides polychètes inféodées aux sources hydrothermales sous-marine: systématique, biologie et écologie. Can J Zool 64:2227-2245

Fustec A, Desbruyères D, Juniper SK (1987) Deep-sea hydrothermal vent communities at $13 \mathrm{~N}$ on the East Pacific Rise: microdistribution and temporal variations. Biol Oceanogr 4:121-164

Gebruk AV, Chevaldonné P, Shank T, Lutz RA, Vrijenhoek RC (2000) Deep-sea hydrothermal vent communities of the Logatchev area $\left(14^{\circ} 45^{\prime} \mathrm{N}\right.$, Mid-Atlantic Ridge): diverse biotopes and high biomass. J Mar Biol Assoc UK 80:383-393

Guillou M, Hily C (1983) Dynamics and biological cycle of a Melinna palmata (Ampharetidae) population during the recolonisation of a dredged area in the vicinity of the harbour of Brest (France). Mar Biol 73:43-50

Grassle JF (1986) The ecology of deep-sea hydrothemal vent communities. Adv Mar Biol 23:301-362

Hessler RR, Smithey WM (1983) The distribution and community structure of megafauna at the Galapagos Rift hydrothermal vents. In: Rona PA, Bostrom K, Laubier L, Smith KL (eds) Hydrothermal processes at seafloor spreading centers. Plenum Press, New York, p 735-770

Hessler RR, Smithey WM, Keller CH (1985) Spatial and tem- 
poral variation of giant clams, tubeworms and mussels at deep-sea hydrothermal vents. In: Jones ML (ed) Hydrothermal vents of the eastern Pacific: an overview. Bull Biol Soc Wash 6:411-428

Hutchings PA (1973) Gametogenesis in a Northumberland population of the polychaete Melinna cristata. Mar Biol 18: 199-211

Jollivet D, Empis A, Baker MC, Hourdez S, Comtet T, JouinToulmond C, Desbruyères D, Tyler PA (2000) Reproductive biology, sexual dimorphism and population structure of the deep-sea hydrothermal vent scale worm Branchipolynoe seepensis (Polychaeta: Polynoidae). J Mar Biol Assoc UK 80:55-68

Juniper SK, Jonasson IR, Tunnicliffe A, Southward AJ (1992) Influence of a tube-building polychaete on hydrothermal chimney mineralization. Geology 20:895-898

Juniper SK, Fisher C, Delaney J (1996) Report on ROPOS submersible operations on the RV 'Thomas G Thompson' cruise: 12-27 August 1996. InterRidge News 5(2):25-26

Lutz RA, Kennish MJ (1993) Ecology of deep-sea hydrothermal vent communities: a review. Rev Geophys 31:211-242

Lutz RA, Shank TM, Fornari DJ, Haymon RM, Lilley MD, Von Damm KL, Desbruyères D (1994) Rapid growth at deepsea vents. Nature 381:663-664

Marsh AG, Mullineaux LS, Young CM, Manahan DT (2001) Larval dispersal potential of the tubeworm Riftia pachyptila at deep-sea hydrothermal vents. Nature 411:77-80

Martineu P, Juniper SK, Fisher CR, Massoth G (1997) Sulfide binding in the body fluids of hydrothermal vent Alvinellid polychaetes. Physiol Zool 70:578-588

McHugh D (1989) Population structure and reproductive biology of two sympatric hydrothermal vent polychaetes, Paralvinella pandorae and P. palmiformis. Mar Biol 103: 95-106

McHugh D, Tunnicliffe V (1994) Ecology and reproductive biology of the hydrothemal vent polychaete Amphisamytha galapagensis (Ampharetidae). Mar Ecol Prog Ser 106:111-120

Olive PJW (1970) Reproduction of a Northumberland population of the polychaete Cirratulus cirratus. Mar Biol 5: 259-273

Olive PJW (1984) Environmental control of reproduction in Polychaeta. In: Fischer A, Pfannensteil HD (eds) Polychaete reproduction, progress in comparative reproductive biology. Gustav Fischer Verlag, New York, p 17-39

Olive PJW, Clark RB (1978) Physiology of reproduction. In: Mill PJ (ed) Physiology of annelids. Academic Press, London, p 271-368

Ramirez Llodra E, Tyler PA, Copley JTP (2000) Reproductive biology of three caridean shrimp, Rimicaris exoculata, Chorocaris chacei and Mirocaris fortunata (Caridea: Decapoda), from hydrothermal vents. J Mar Biol Assoc UK 80: $473-484$

Editorial responsibility: Roger Hughes (Contributing Editor), Bangor, Wales, UK
Robigou V, Delaney JR, Stake DS (1993) Large massive sulfide deposits in a newly-discovered active hydrothermal system: the High Rise vent field, Endeavour Segment, Juan de Fuca Ridge. Geophys Res Lett 20:1887-1890

Sarrazin J, Juniper SK (1999) Biological characteristics of a hydrothermal edifice mosaic community. Mar Ecol Prog Ser 185:1-19

Sarrazin J, Robigou V, Juniper SK, Delaney JR (1997) Biological and geological dynamics over four years on a hightemperature hydrothermal sulfide structure at the Juan de Fuca Ridge hydrothermal observatory. Mar Ecol Prog Ser 153:5-24

Sarrazin J, Juniper SK, Massoth G, Legendre P (1999) Physical and chemical factors influencing species distributions on hydrothermal sulfide edifices of the Juan de Fuca Ridge, northeast Pacific. Mar Ecol Prog Ser 190:89-112

Schultz A, Elderfield H (1997) Controls on the physics and chemistry of seafloor hydrothermal circulation. Phil Trans R Soc Lond A 335:387-425

Segonzac M (1992) Les peuplements associés à l'hydrothermalisme océanique du Snake Pit (dorsale médioatlantique; $23^{\circ} \mathrm{N}, 3480 \mathrm{~m}$ ): composition et microdistribution de la mégafaune. CR Acad Sci Paris Sér III 314:593-600

Southward EC, Tunnicliffe V, Black M (1995) Revision of the species of Ridgeia from northeast Pacific hydrothermal vents, with a redescription of Ridgeia piscesae Jones (Pogonophora: Obturata $=$ Vestimentifera). Can J Zool 73: 282-295

Tunnicliffe V, Juniper SK (1990) Dynamic character of the hydrothermal vent habitat and the nature of sulfide chimney fauna. Prog Oceanogr 24:1-13

Tunnicliffe V, Desbruyères D, Jollivet $D$, Laubier L (1993) Systematic and ecological characteristics of Paralvinella sulfincola Desbruyères and Laubier, a new polychaete (family Alvinellidae) from northeast Pacific hydrothermal vents. Can J Zool 71:286-297

Tyler PA (1988) Seasonality in the deep-sea. Oceanogr Mar Biol Annu Rev 26:227-258

Tyler PA, Young CM (1999) Reproduction and dispersal at vents and cold seeps. J Mar Biol Assoc UK 79:193-208

Van Dover CL, Desbruyères D, Segonzac M, Comtet T, Saldanha L, Fiala-Medioni A, Langmuir C (1996) Biology of the Lucky Strike hydrothermal vent field. Deep-Sea Res 43:1509-1529

Zal F, Desbruyères D, Jouin-Toulmound C (1994) Sexual dimorphism in Paralvinella grasslei, a polychaete annelid from deep-sea hydrothermal vents. CR Acad Sci Paris Sér III 317:42-48

Zal F, Jollivet D, Chevaldonné $P$, Desbruyères D (1995) Reproductive biology and population structure of the deep-sea hydrothermal vent worm Paralvinella grasslei (Polychaeta: Alvinellidae) at $13 \mathrm{~N}$ on the East Pacific Rise. Mar Biol 122:637-648

Submitted: July 14, 2002; Accepted: March 27, 2003

Proofs received from author(s): June 11, 2003 